\title{
Correction to: Agroforestry can enhance foraging and nesting resources for pollinators with focus on solitary bees at the landscape scale
}

\author{
Sonja Kay (D) Elisabeth Kühn • Matthias Albrecht - Louis Sutter • \\ Erich Szerencsits $\cdot$ Felix Herzog
}

Published online: 9 June 2021

(C) Springer Nature B.V. 2021

Correction to: Agroforest Syst (2020) 94:379-387

https://doi.org/10.1007/s10457-019-00400-9

This article should be considered to be part of the special issue Agroforestry and the Environment but was accidentally published in a regular issue (Volume 94, Issue 2) of this journal. The article and their full references are listed below.

Kay S, Kühn E, Albrecht M, Sutter L, Szerencsits E, Herzog F (2020) Agroforestry can enhance foraging and nesting resources for pollinators with focus on solitary bees at the landscape scale. Agroforest Syst 94:379-387. https://doi.org/10.1007/s10457-01900400-9.

Publisher's Note Springer Nature remains neutral with regard to jurisdictional claims in published maps and institutional affiliations.
The original article can be found online at https:// doi.org/10.1007/s 10457-019-00400-9.

S. Kay $(\bowtie) \cdot$ E. Kühn $\cdot$ M. Albrecht .

L. Sutter · E. Szerencsits · F. Herzog

Agroscope, Research Group Agricultural Landscapes and

Biodiversity, Zurich, Switzerland

e-mail: sonja.kay@agroscope.admin.ch 